\title{
Finding Alcatrazes and early Luso-African settlement on Santiago Island, Cape Verde
}

Christopher Evans ${ }^{1, *} \&$ Marie Louise Stig Sørensen ${ }^{1, *}$, with Michael J. Allen ${ }^{2}$, Jo Appleby ${ }^{3}$, Tania Manuel Casimiro ${ }^{4}$, Charles French ${ }^{1}$, Sarah Inskip ${ }^{1}$, Jose Lima ${ }^{5}$, Richard Newman ${ }^{1}$, Konstantin Richter ${ }^{6} \&$ Rob Scaife ${ }^{7}$

After the Portuguese discovered the Cape Verde Islands in AD 1456 they divided its main island, Santiago, into two governing captaincies. The founding settlement in the southwest, Cidade Velha, soon became the Islands' capital and a thriving trade centre; in contrast, that in the east, Alcatrazes, only lasted as an official seat from 1484-1516 and is held to have 'failed' (see Richter 2015).

Lying approximately $500 \mathrm{~km}$ off the west coast of Africa (Figure 1), there is no evidence that the archipelago had any indigenous population. Underpinned by the slave trade, the islands are a 'place of arrivals' - of animals, plants and people (see Sørensen et al. 2011; Evans et al. 2012; Evans \& Sørensen 2016). Their initial colonisation related to Portugal's expansion along Africa's coast. With the discovery of Brazil in AD 1500, Cape Verde and, in particular, Cidade Velha — with Africa's first cathedral and hospital—flourished as a crossroads of the Atlantic slave trade.

The general location of Alcatrazes has long been known on the basis of place-name evidence and the remains of a ruined gothic church, Nossa Senhora da Luz (Figure 1). It was only in 2012, however, that the associated settlement was located, as well as other significant sites in its environs, including an early Luso-African settlement.

\section{The church investigations}

In advance of restoration, investigation of the church began in 2011. Despite extensive modification of the building fabric over time, excavations within its interior revealed its

\footnotetext{
Division of Archaeology, University of Cambridge, Downing Street, Cambridge CB2 3DZ, UK

Allen Environmental Archaeology, Redroof, Green Road, Codford St Peter, Warminster BA12 ONW, UK

Archaeology and Ancient History, University of Leicester, University Road, Leicester LE1 7RH, UK

Faculdade de Ciências Sociais e Humanas, Universidade Nova de Lisboa, Avenida de Berna 26 C, 1069-061

Lisboa, Portugal

Instituto do Património Cultural, Ministerio da Cultura, Praia, Cabo Verde

6 Independent researcher, Dorfstraße 21, 26441 Jever, Germany

7 Palaeoenvironmental Laboratory, Geography and Environment, University of Southampton, University Road, Southampton SO17 1BJ, UK

* Authors for correspondence (Email: cje30@cam.ac.uk; mlss@cam.ac.uk)
}

(C) Antiquity Publications Ltd, 2017

ANTIQUITY 91358 , e8 (2017): 1-9

doi:10.15184/aqy.2017.104 
Christopher Evans et al.
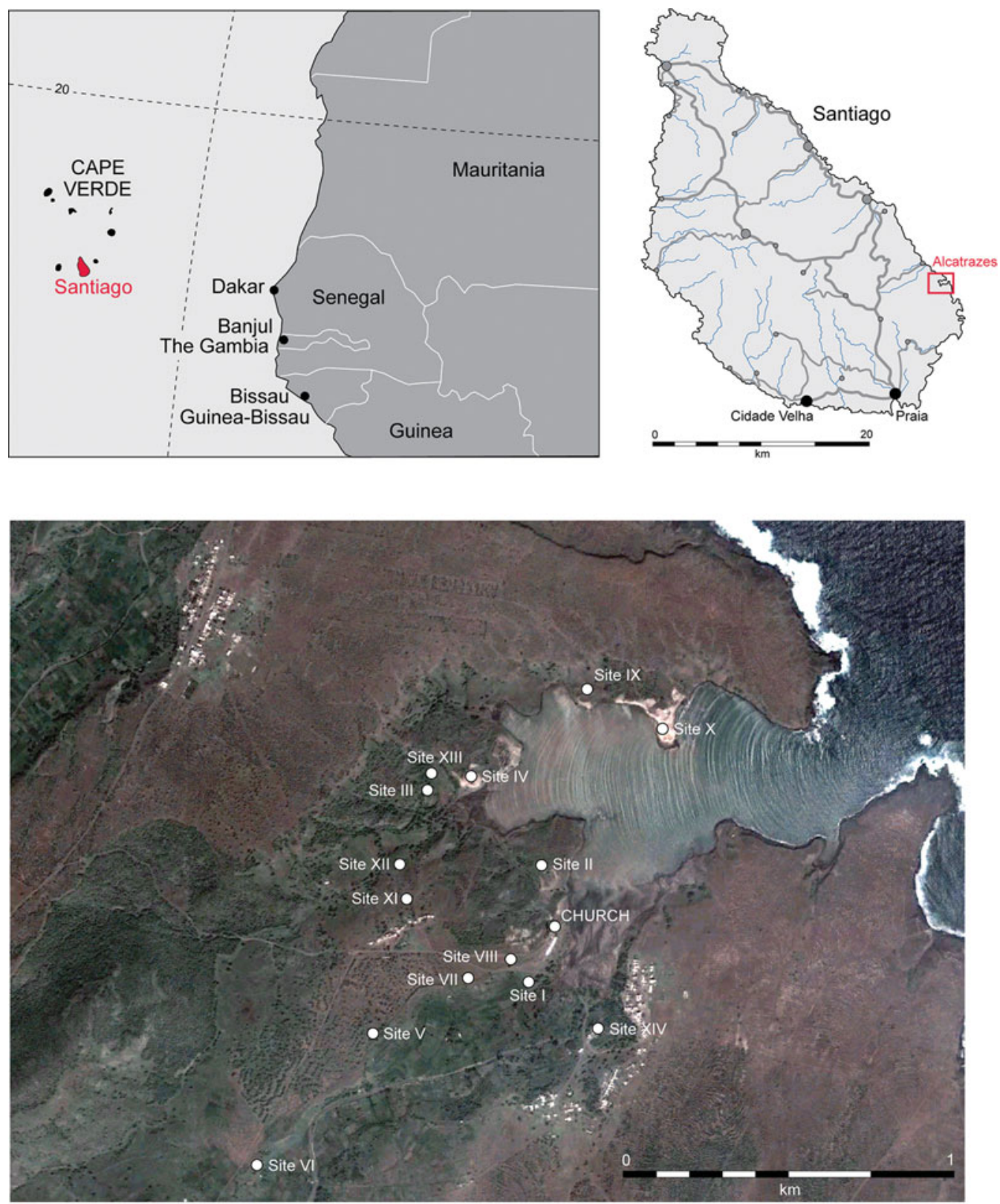

Figure 1. Alcatrazes: location maps and site-survey plot.

original form as a simple rectangular nave and chancel (Figure 2). In addition, various architectural details, such as daises, fonts and arch capitals-one with a locally inspired lizard carving (Figure 3)—were recorded, and sixteenth-century, Moorish-influenced tiles were retrieved.

Prior to the mid nineteenth century, burial was common within the interior of churches. More than 2000 teeth were recovered by reducing the church's earthen floor-level by (C) Antiquity Publications Ltd, 2017 
Finding Alcatrazes and early Luso-African settlement on Santiago Island, Cape Verde
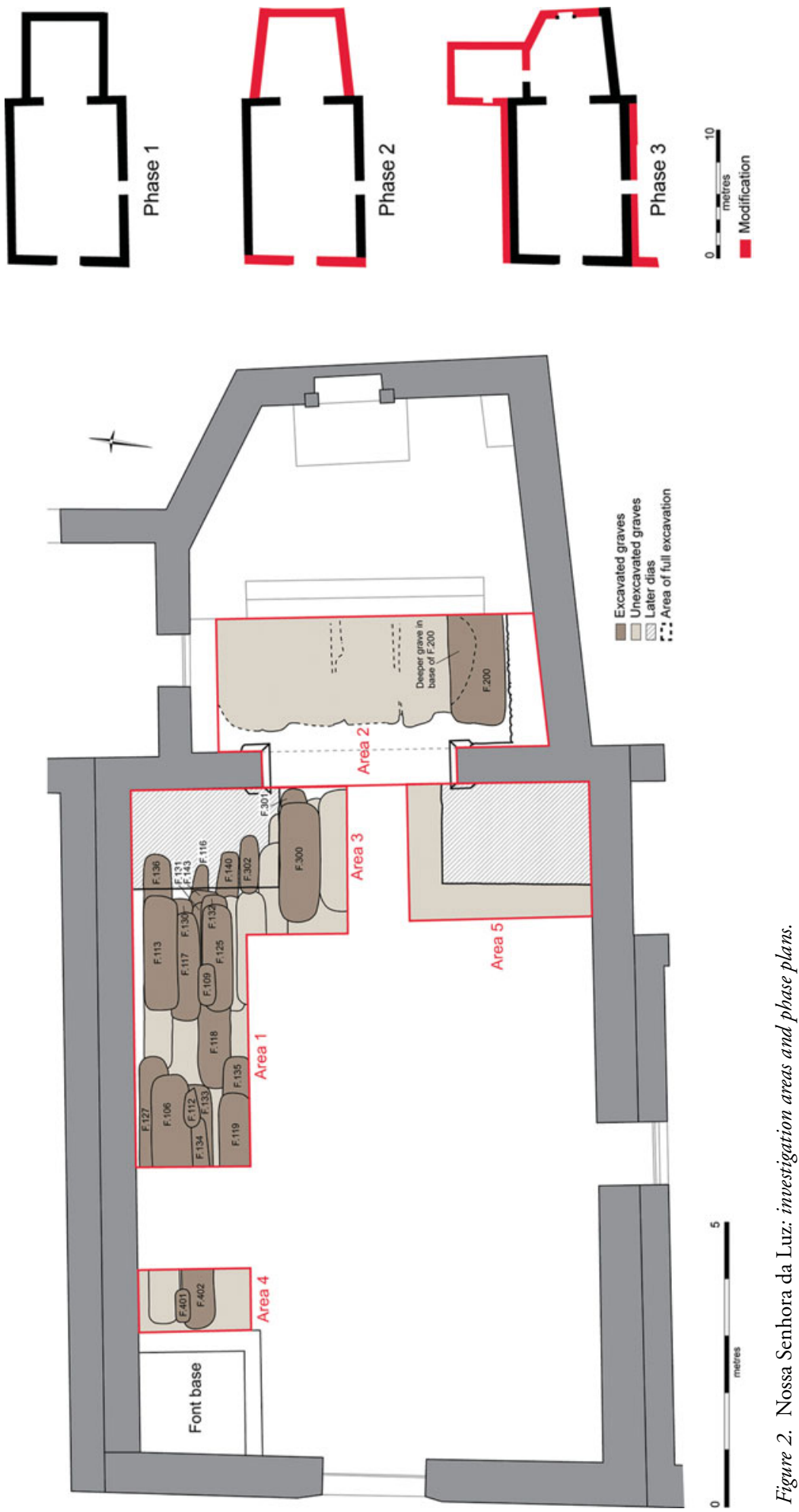

(C) Antiquity Publications Ltd, 2017 

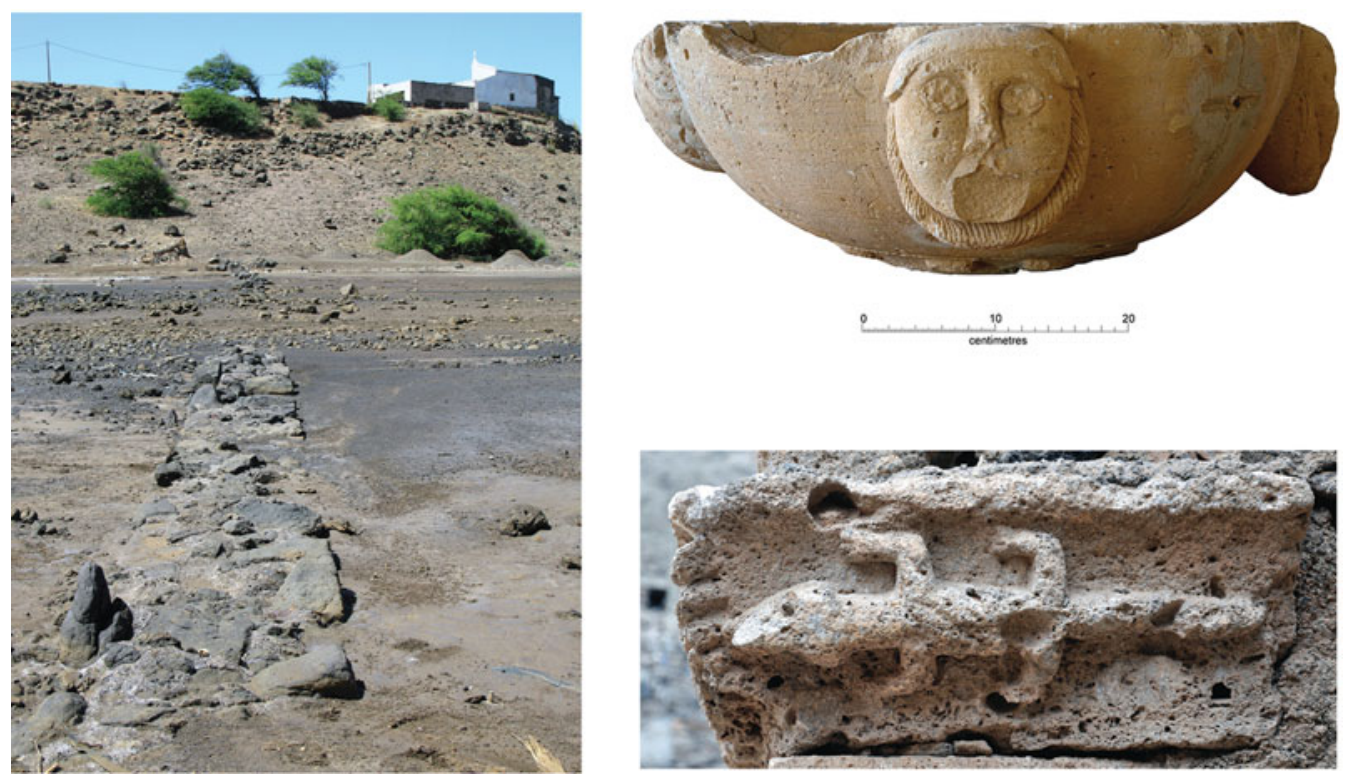

Figure 3. Left) Nossa Senhora da Luz situated on the plateau-rise above and, in the foreground, the sea wall; top right) the church's decorated baptismal font; bottom right) its lizard-decorated capital.

$0.15 \mathrm{~m}$, indicating a significant burial sequence. Surface plans of graves were distinguished in two areas, and 30 graves were excavated in Area 1/3 (Figure 4). The earliest graves had been dug directly into the bedrock; in many instances, the surviving skeletons were only partial due to the intensity of subsequent grave-intercutting. Acidic soil conditions also contributed to the poor survival of bone, although this was mitigated where the deceased had been interred within gypsum-impregnated shrouds. Of the nine skeletons examined in detail by Jo Appleby, four suffered from degenerative joint disease and one had multiple traumas.

The teeth, studied by Sarah Inskip, have trait prevalences common to both Sub-Saharan Africans and Europeans. A number of teeth display wear consistent with pipe-smoking. There is also evidence of periodontal disease, and approximately 22 per cent have linear enamel hypoplasia, which is indicative of poor diet, ill health and/or stress. While it is probable that the individuals suffered from a range of infectious diseases, the most significant indicators are consistent with congenital syphilis.

A number of beads were recovered from the graves, usually around the hands and pelvis area. The majority were of bone, with some of clay; in several instances, these clearly represented rosaries. The density of the graves suggests that there may be more than 1000 within the church's interior. There are few finds with which to date the graves; although they could represent a short-lived sequence, burial probably continued from the sixteenth to nineteenth centuries. Indeed, this seems probable as the parish of Nossa Senhora da Luz dos Alcatrazes, when it was created in 1572, had some 200 inhabitants, attesting to the area's occupation after the transfer of the captaincy.

(C) Antiquity Publications Ltd, 2017 

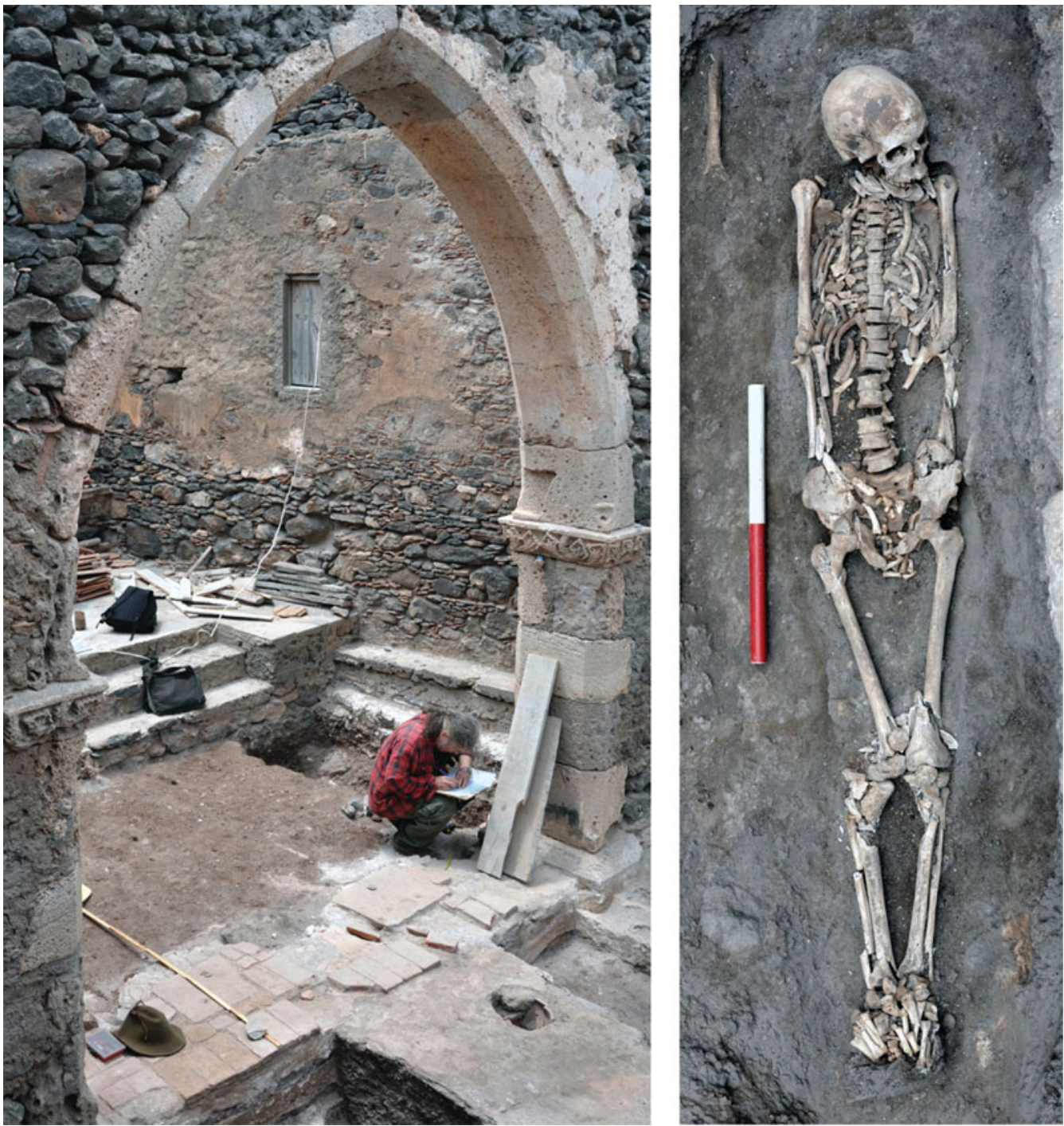

Figure 4. Nossa Senhora da Luz: left) fabric recording; right) burial.

\section{The Portuguese settlement}

Today's villages lie on the plateau on either side of a 90m-deep valley. These date back to the last century and are only viable because of the use of mechanically driven wells; an earlier settlement was probably located with easier access to water. A clue to the location of this settlement is a masonry sea wall, which, at low tide, can be traced across the embayment's western end (see Figure 3). Based on experience gleaned at Cidade Velha, it was thought that this feature was probably early and that the settlement therefore lay immediately behind it on the lower valley terraces. Although no upstanding structures could be identified in this area, our survey located masonry exposed in a gully (Site I). 
Excavations at Site I revealed parts of two buildings with plaster-covered, mortar-bonded walls, standing $0.25-0.80 \mathrm{~m}$ high (Figure 5). The building techniques indicate a Portuguesephase attribution, as do early glass shards and pottery (the imported sherds are generally of sixteenth- to nineteenth-century date). Aside from an English-sourced stoneware and three locally made sherds, all the ceramics were of Portuguese or Spanish origin (studied by Tania Manuel Casimiro). Two Lisbon mint coins were also found, one a 1481-1495 issue. The ceramic date range indicates a degree of local settlement continuity after the transfer of the captaincy in 1516 .

A geoarchaeological programme was undertaken by Charles French and Mike Allen across the north-eastern end of the valley floor. A key discovery was a waterlogged palaeochannel beside Site I. Rob Scaife's preliminary analysis of well-preserved but limited pollen from this channel relates mostly to grasses and pollen from what is probably a clovertype. The absence of tree pollen is consistent with early descriptions of the Islands; the channel's basal deposit is dated to 1160-1260 cal AD (Beta-341493).

Portuguese-phase settlement was found at only one other location, Site XIV, where 'early' mortared masonry occurs beneath the modern buildings. It may have been the site of another church/chapel, but its name_Castelinho_-suggests a fortified residence.

\section{Survey sites}

A walk-over field survey covering $1.6 \mathrm{~km}^{2}$ was conducted along either side of the embayment. Most of the sites found were of recent, nineteenth- to twentieth-century date: isolated houses, animal pens and fishermen's shelters. Three, however, are of greater significance. Site XII is marked by low mounds and cobbled surfaces; as well as sea shells and much roof tile, there were seventeenth-century Portuguese sherds. According to map evidence, this must be the remains of a convent (Covao de Santana). The other two sites of interest were subject to limited trial trenching. Site II consisted of at least four buildings, the largest with a three-room range $(15.5 \mathrm{~m}$ long) surviving to $0.8 \mathrm{~m}$ in height. Pottery suggests occupation from the seventeenth to nineteenth centuries.

Site III represents a major discovery (Figure 6). It consists of three main buildings covering $25 \times 40 \mathrm{~m}$, plus paved surfaces, stone cairns and terrace walls. Building 1 is $15 \times 7 \mathrm{~m}$ and its drystone earthen-bonded walls stand to around $0.5 \mathrm{~m}$. While there are similarities with the main building at Site II, there is no evidence at Site III that the building's roof was tiled. A sondage within its central room revealed an earthen floor-level, upon which was a dump of $150+$ limpet shells and large sherds of locally made pottery ('Pottery Africane'). Considerable quantities of these unglazed wares occur across the site, with very few imported ceramics (all of which are of seventeenth-century date). A charred seed/nutlet recovered from the floor deposit provides a radiocarbon date calibrating to 1650-1680 and 1730-1810 and 1930-post-1950 AD (100土30 BP; Beta-341494). In light of this date, the finds recovered and the distance of the site from the town, this appears to be a distinctly Luso-African settlement, reflecting the 'mixed traditions' of the post-Portuguese occupation phase of Alcatrazes.

Site III currently represents the earliest such settlement known on the Islands. The only similar excavated sites-the shell middens at Salamanza and the bay of Joao D'Evora on (C) Antiquity Publications Ltd, 2017 
Finding Alcatrazes and early Luso-African settlement on Santiago Island, Cape Verde
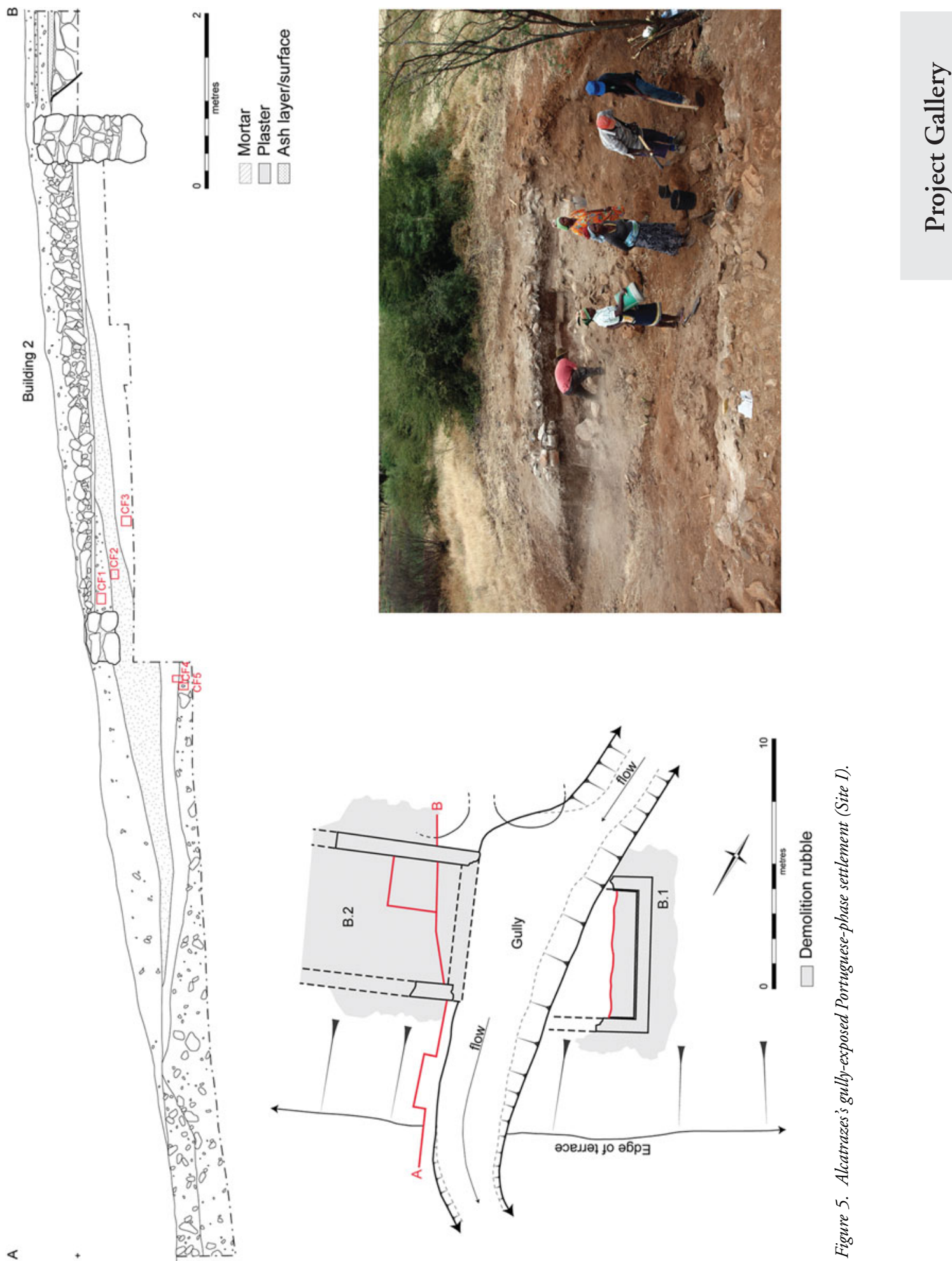

C) Antiquity Publications Ltd, 2017 

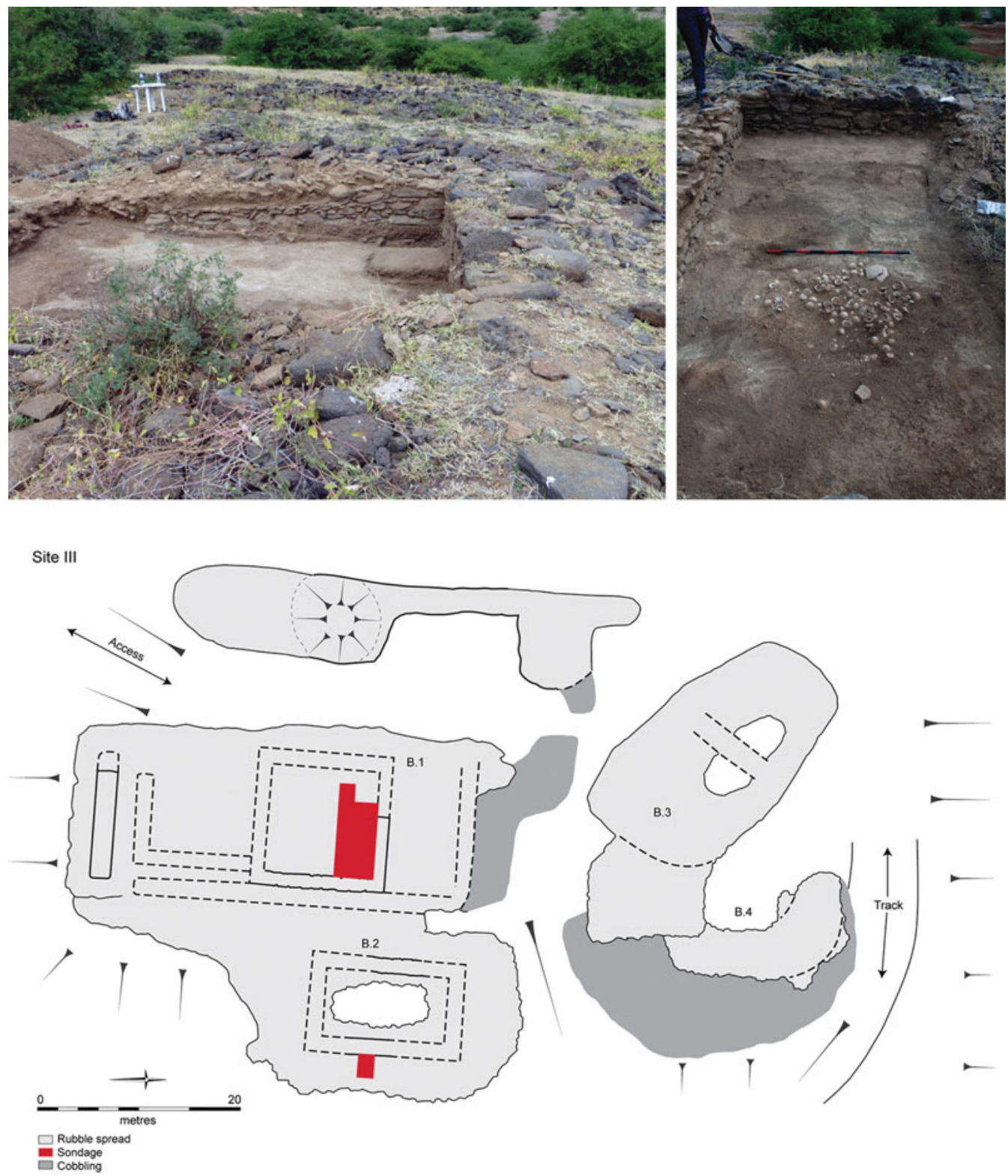

Figure 6. The Luso-African settlement (Site III); top) building 1's sondage.

the Island of St Vicente to the north-date to the eighteenth century (Rodrigues 2001). These sites provide an unexpected Antiquity connection. The first formally identified (non-standing) 'sites' on the Islands, they were noted by O.G.S. Crawford in 1913. The circumstances of their discovery are extraordinary (e.g. van Tilburg 2002). The young Crawford had signed onto the Mana expedition and set sail for Easter Island with the Routledges. Seriously falling out with the couple in charge, he left the ship at the British (C) Antiquity Publications Ltd, 2017 
coaling station of Mindelo on St Vicente, and it was then, awaiting return passage to Liverpool, that he found the sites.

As to the future, next year we intend to undertake a final season of fieldwork at Alcatrazes. This will have two main aims. First, to trace the extent of Site I's early Portuguese settlement further, and, second, to continue investigations of Site III for its rare insights into the early Luso-African settlement of Cape Verde.

\section{Acknowledgements}

The work was undertaken in partnership with the Islands' Ministério da Cultura; we are grateful for the full cooperation of our Instituto do Património Cultural colleagues. The church investigations were largely funded by Cambridge's McDonald Institute for Archaeological Research, with the environs' survey and settlement excavations funded by National Geographic (GEFNE21-11). Drawings are by Vicki Herring, and photographs by Christopher Evans, Richard Newman and Dave Webb.

\section{References}

Evans, C. \& M.L.S. Sørensen. 2016. A place of arrivals: forging a nation's identity at Cidade Velha. Current World Archaeology 75: 32-36.

Evans, C., M.L.S. Sørensen \& K. Richter. 2012. An Early Christian church in the Tropics: excavation of the N.S. da Conceição, Cidade Velha, Cape Verde, in T. Green (ed.) Brokers of change: Atlantic commerce and cultures in Precolonial Western Africa (Proceedings of the British Academy 178): 173-92. Oxford: Oxford University Press.

Richter, K. 2015. Gone with the wind ... why Alcatrazes, the second European tropical settlement, vanished. Mande Studies 16-17: 119-67.
Rodrigues, M.C. 2001. Contribuição para o Estduo de Estações Arquehistóricas em Cabo Verde: os concheiros de Salamanza e João D'Évora Ilha de S. Vicente [Contribution for the study of archaeo-historical stations in Cape Verde: the shell middens of Salamanza and João D' Évora, Island of S. Vicente]. Portugalia 21-22: 249-80.

Sørensen, M.L.S., C. Evans \& K. Richter. 2011. A place of history: archaeology and heritage at Cidade Velha, Cape Verde, in P. Lane \& K. MacDonald (ed.) Slavery in Africa: archaeology and memory (Proceedings of the British Academy 168): 421-42. Oxford: Oxford University Press.

van Tilburg, J.A. 2002. O.G.S. Crawford and the Mana expedition to Easter Island (Rapa Nui), 1913-1915. Journal of the Polynesian Society 111: 65-78. 